УДК 35.072.2-044.372(043.2)

DOI: $10.34132 /$ pard2021.13.08

\title{
ТЕОРЕТИКО-МЕТОДОЛОГІЧНІ ОСНОВИ ДОСЛІДЖЕННЯ КРИЗ У ПУБЛІЧНОМУ УПРАВЛІННІ
}

Соколов О. $\boldsymbol{C}$., аспірант, Національний університет біоресурсів і природокористування України, м. Київ, Україна.

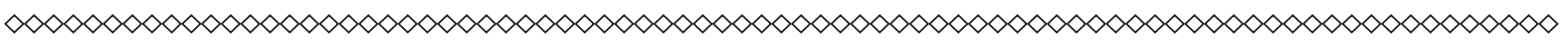

Мета статті полягає у визначенні теоретико-методологічних основ дослідження криз у публічному управлінні. Методологічну основу дослідження становлять загальні теоретичні методи (аналізу та синтезу), а також принциии історизму, об 'єктивності та науковості. Наукова новизна полягає в унікальному авторському визначенні та аналізі криз у публічному управлінні. Висновки. Досліджено, щзо криза у загальному розумінні - ие нестабільний або критичний період, щуо неминуче призводить до змін й містить високу ймовірність вкрай небажаних наслідків. У свою чергу, «криза публічного управління» - ие особлива форма системи органів державної влади та громадянського суспільства, щуо супроводжується нестабільністю, зниженням рівня керованості сочіально-економічного прочесами, розбалансованістю політичних інститутів, загостренням соиіальних конфліктів, наростанням протиріч в суспільстві тощзо. Така криза призводить до зниження результативності та ефективності управлінського впливу на сочіально-економічні прочеси.

Визначено основні ознаки кризи публічного управління. Поперше, це загострення економічних і соціальних конфліктів. Подруге, изе нездатність держсавної влади керувати конфліктами та регулювати сочіально-економічні прочеси $i$ відносини колишніми традииійними методами.

Розглянуто кризу як складний феномен, щзо охоплює широкий спектр подій. Ці події можуть відрізнятися за своїм масштабом, причинами, тривалістю, серйозністю наслідків тощяо, однак їх 
єднає те, щзо вони становлять загрозу основним інтересам й репутації організації, уряду чи держави, потребують негайного реагування й застосування нетрадииійних засобів врегулювання, суттєво змінюють ситуацію, нормальний хід життя суспільства й відносини між учасниками конфлікту. Проаналізовано, щэо кризи публічного управління бувають як легкі так $і$ глибокі, як короткочасні так $i$ затяжні, як локальні так і суцільні, як приховані так і явні, як гострі так і хронічні. 3'ясовано, щзо у разі ігнорування або несвоєчасного реагування на кризи, вони здатні не лише завдати матеріальних збитків, але й негативно вплинути на иілі організації та держави.

Ключові слова: державна влада, криза, методологія, публічне управління, теорія.

Постановка проблеми у загальному вигляді. Дослідження криз можна вважати відносно молодою сферою наукового пізнання: попит на такий вид знання виник у США в 70-ті роки XX століття. Теоретичні розробки з цієї тематики були зосереджені на наступних аспектах: на визначенні, класифікації та етапах розвитку криз, на особливостях кризових комунікацій та прийнятті рішень у кризових умовах. Врешті-решт, дослідницький фокус був зосереджений на стратегії управління кризами, попередженні криз тощо.

Однак, досі актуальними, дискусійними залишаються такі питання, як «Що таке криза публічного управління?» і «Які іiі основні ознаки та види?». Усе це описує проблему і зумовлює актуальність дослідження.

Аналіз останніх досліджень і публікацій. У загальному розумінні проблематику виявлення соціальної напруженості, криз, конфліктів (соціальнополітичних, публічного управління тощо), суспільної модернізації, застосування антикризових технологій, антикризового управління досліджували як зарубіжні вчені Г. Алмонд, Р. Даль, Р. Дарендорф, Е. Дюркгайм, Р. Мертон, Т. Парсонс, так і українські: В. Авер'янов, В. Матвієнко, В. Тертичка, В. Тронь, О. Хворостяний, А. Чернявський тощо. 
У нашому дослідженні ми використовували теоретичні розробки даних класичних авторів, а також праці сучасників: В. Герасенко, Г. Купряшин, Б. Мильнер, Е. Коротков, А. Зуб, Л. Костецька тощо.

Формулювання цілей статті (постановка завдання). Метою статті є систематизація теоретичного фундаменту для подальшого дослідження криз у публічному управлінні.

Виклад основного матеріалу дослідження. Перш ніж дати визначення кризі публічного управління і зрозуміти, у чому така криза проявляється, слід спершу прояснити, що означає «криза» у загальному, широкому розумінні.

Аналогічно до більшості соціальних феноменів, у сучасному науковому дискурсі не існує єдиної дефініції «кризи». 3 одного боку, це ускладнює розуміння цієї категорії, а з іншого, дозволяє нам розглянути іiі максимально широко, з позицій різних дослідників, беручи до уваги їі найбільш неочевидні, приховані особливості.

Починаючи 3 етимології слова, слід зазначити, що слово «криза» виникло у Греції. Як зазначає А. Сгоров грецьке «крі́бı૬» походить від дієслова «крі́vю», що означає «визначати, вибирати», який міцно увійшов в античну судову практику і позначав всі дії судового процесу: звинувачення, ведення судового процесу, змагання сторін, а також винесення вироку, при цьому зберігаючи загальне значення «ведення справи в суді». 3 часом «крі́бıৎ» набув і кілька нових значень: ним почав позначатись результат (битви), суперечка, змагання, тлумачення (сну) [21].

У словнику Вебстера «криза» визначається як:

1) вирішальний момент (як у літературному сюжеті, де криза вистави трапляється в 3-му акті);

2) нестабільний або вирішальний час чи стан справ, у яких насувається рішуча зміна (особливо такий, що містить загрозу вкрай небажаного результату: фінансова криза, енергетична криза країни);

3) ситуація, яка досягла критичної фази (екологічна криза, криза безробіття) [17].

Отже, криза визначається як певна ситуація, що руйнує традиційні механізми подолання проблем. Така ситуація 
характеризується ризиком, загрозою виведення з ладу суспільних систем, тим самим впливаючи на якість життя багатьох людей [2].

В інформаційному просторі кризою вважають подію або низку подій, які перетворюють організацію або уряд держави на об’єкт пильної уваги засобів масової інформації та громадськості. У сфері суспільних відносин кризи розглядаються, перш за все, як надзвичайні події, що порушують життєдіяльність різних суспільних груп, ставлячи під загрозу репутацію, цілісність або навіть виживання суспільної організації.

Такими подіями можуть бути як природні катастрофи, так i техногенні аварії (повені, пожежі, землетруси, викиди шкідливих речовин). Окремо розглядаються кризи, спричинені людською діяльністю (свідомою чи несвідомою). До таких криз можна віднести і авіакатастрофи, і терористичні акти, і страйки. Криза може бути результатом неналежного виконання посадових обов'язків, вона може бути викликана зміною моделі поведінки і ціностей [2].

Однак, деякі дослідники вбачають у кризових явищах не лише негативний, а й позитивний вплив на систему. Наприклад, К. Завтій та К. Мірко у своїй статті визначали кризу так: «Криза це переломний момент у розвитку суспільства, який створює попит на соціальні, економічні, політичні зміни тощо. Криза здатна змінювати основні тенденції життєдіяльності системи, тим самим порушуючи іiі стійкість і радикальним чином оновлюючи іiі. Тому, на думку авторів, очисна сила кризи потрібна системі не менше ніж стабільне функціонування і розвиток. Одне не може існувати без іншого, це своєрідний закон єдності і боротьби протилежностей. Без боротьби немає розвитку» [12].

У соціальних науках традиційно існує три школи, три основні підходи до визначення «кризи» [5].

Перша школа - «об’єктивна школа», яка визначає кризу як «загальноприйнятий факт», незалежний від суб'єктивних інтерпретацій. Даний напрямок досліджень політичних наук характеризується наявним позитивізмом (в основі лежить припущення, що навколишній світ можна виміряти та оцінити кількісно, нехтуючи суб'єктом дослідження). Інакше кажучи, 
прихильники такої точки зору стверджують, що ми, як спостерігачі соціального світу, можемо вивчати суспільні явища як «факти», які можна визначити і виміряти.

Застосування позитивізму до явища кризи передбачає припущення, що кризи - це «конкретні» події, які можна визначити числом ключових характеристик. Позитивістський підхід передбачає наявність кризових критеріїв, що допомогли би з'ясувати, чи існує криза. Цей підхід корисний перш за все тим, що він починає деталізувати та закріплювати ті компоненти, які становлять «фундамент» будь-якої кризи. Традиційно вважається, що наявність трьох умов кризи підтверджують іï наявність, а саме наявність важкої загрози, високого рівня невизначеності та нагальна потреби вжити заходів.

До об'єктивних чинників криз можна віднести:

- кризи життя (повінь, залізнична катастрофа, пожежа, вірус пандемії);

- кризи критичної інфраструктури (відключення електроенергії, обвал мереж зв>язку тощо);

- кризи функціонування політики (випадково розкривши інформацію розвідки, що серйозно компрометує таємні операції розвідки);

- кризи економічної життєздатності (масові скорочення бюджету організації);

- криза політичної репутації (високий рівень невдоволення громадян у соціологічних опитуваннях).

Друга школа - «суб'єктивна школа», що визначає кризу як предмет суб'єктивного сприйняття та усвідомлення. Основна увага приділяється тому, як ми сприймаємо та будуємо навколишній світ, а не припускаємо, що це лише незмінні «факти». Переведення цієї школи мислення у кризові терміни свідчить про те, що якщо ми відчуваємо та віримо, що явище, подія чи епізод є кризою, то це справді «криза», і це «справжнє», тому що ми використовуємо мову, щоб передати значення того, що відбувається.

Просту версію «кризи як сприйняття» можна знайти у поширених припущеннях про те, що кризи є очевидними. Нам не 
потрібні критерії, контрольні списки, правила чи словники, щоб сказати нам, що таке криза. Криза просто «є», і ми відчуваємо іiі серцем. Дана точка зору також зачіпається у багатьох наукових працях (зокрема, у тих, що зосереджуються на корпоративній кризі), але іiі можна знайти загальніше у висвітленні 3МI криз та катастроф. Наприклад, коли газетні журналісти пишуть про війни, голод та масштабні катастрофи, такі як 11 вересня, ураган «Катріна» або японське цунамі, термін «криза» вважається самоочевидним, виходячи з припущення, що ці епізоди не можуть бути нічим іншим, як «кризами».

Для даного підходу вкрай важливими $є$ тези про те, що переживання у кожного різні, і що досвід обумовлює будь-які сприйняття. Деякі люди будуть відчувати більшу чи меншу загрозу подій, залежно від таких факторів, як їх географічне розташування, ступінь їх участі (якщо взагалі є), ймовірний вплив на їхні особисті обставини та ступінь, у якому це явище включає ïx основні переконання та припущення. Візьмемо для прикладу «арабську весну». Для могутніх еліт, контролюючих держави, «арабська весна» була величезною кризою, що створювала їх подальшому існуванню. Проте для тих, хто протестував на вулицях, протести були не стільки загрозливою кризою, скільки можливістю створити позитивні для себе зміни. А для тих 3 нас, хто дивився на події здалеку, характерним було відчуття кризи без будьякої безпосередньої загрози. Тому важливо розуміти, що ці різні сприйняття не зливаються в одне безперечне визначення. Одні події можуть сприйматись як криза, інші - як можливість до змін.

Третя школа виникла у якості певного компромісу між першими двома. Вона увібрала в себе основні положення як першої, так і другої школи. Вона почала називатись «кризою критичного реалізму».

Критичний реалізм - це щось на кшталт загального терміну для різних методологічних позицій, спроба поєднати «факти» та «сприйняття», засновані на існуванні реальних і безперечних явищ, на які різні актори можуть дивитися по -різному. Наприклад, ми точно знаємо, що існують великі розбіжності в доходах та статках, але 
ми можемо подивитися такі диспропорції як більш-менш бажані, залежно від наших власних складних і диференційованих світоглядів. Якщо ми застосуємо таке мислення до кризових ситуацій, то стане зрозумілим, що вони є надзвичайно загрозливими умовами, які можуть існувати самі по собі. Та незалежно від того ми маємо 3 ними справу рівно настільки, наскільки ми вважаємо їх значущими, тобто яким чином ми обираємо позначити їх.

Приймаючи критичну реалістичну позицію, автор визначає кризу як «сукупність обставин, за яких окремі особи, установи чи суспільства стикаються з іншими загрозами норми повсякденного щоденного функціонування, але їх значення та вплив обставини будуть змінюватися залежно від індивідуальних уявлень [5].

Взагалі, різні автори наводять різні типології кризових ситуацій у соціальній площині, проте всі види криз характеризуються такими загальними ознаками:

- відсутність ясності щодо причин (внаслідок їх множинності) i наслідків організаційного кризи;

- кризові ситуації - малоймовірні події, які загрожують цілісності та існуванню публічного управління;

- кризові ситуації обмежують час на збір інформації та локалізацію наслідків кризи;

- криза модифікує або навіть паралізує роботу команди топменеджерів;

- криза вимагає від керівництва швидкого прийняття рішень, що мають важливі наслідки для організації.

3 урахуванням цих положень можна дати наступне визначення кризи, яке трактував А. Зуб: криза-це малоймовірна подія, що здатна загрожувати життєдіяльності організації. Вона характеризується невизначеними причинами і важко передбачуваними наслідками, що вимагає прийняття негайних рішень [22].

Як $з$ цього усього визначити саме кризу публічного управління?

Найбільш універсальним, на наш погляд, $\epsilon$ визначення російського дослідника Е. Короткова. На думку автора, криза державного управління - це «особливий переломний стан у розвитку і функціонуванні політичної системи суспільства та 
державно-владних структур, що визначається нестабільністю, розбалансованістю діяльності політичних інститутів, зниженням рівня керованості соціально-економічними процесами, загостренням політичних конфліктів, наростанням критичної активності мас» [11].

Ми визначаємо кризу публічного управління як момент загострення (політичних, економічних, соціальних) протиріч, що призводить до певних змін у системі (організації, державі, тощо).

Тепер варто розглянути основні ознаки кризи публічного управління.

3 одного боку, сутнісними ознаками кризи публічного управління $є$ загострення економічних і соціальних конфліктів. 3 іншого боку, будь-яка криза виражена нездатністю державної влади керувати конфліктами, що перебувають у стані ескалації і загострюються з кожним днем. Зазвичай, у період кризи органи державної влади не здатні регулювати соціально-економічні процеси і відносини колишніми традиційними методами.

Досить інформативно описав ознаки кризи Б. Мілнер. Він зазначав:

На всіх рівнях знижується відповідальність, ігноруються права, розпадаються системи контролю, політичні рішення тяжіють над економічними, рвуться організаційні відносини, відсутній зворотний зв'язок.

Формування ринкових господарюючих суб'єктів різко відстає за часом.

Замість самоврядування, налагодженого механізму регулювання, координації та надійних горизонтальних зв'язків виникає вакуум, що викликає організаційну анархію і зникнення виконавської дисципліни.

Державні структури самоусуваються від вирішення питань, які і в ринковій економіці залишаються в сфері їх компетенції.

Адміністрування як необхідний владний компонент будьякого управління вільно чи мимоволі ототожнюється 3 минулою адміністративно-наказовою системою, в якій воно мало самодостатнє значення. 
Якщо раніше державний вплив було безмежним і повсюдним, то тепер процес багато в чому пущений на самоврядування.

Приватизаційні процеси, лібералізація економіки стикаються і $з$ іншою крайністю, яку можна було б назвати управлінським камуфляжем.

У великих масштабах розростаються недержавні структури спекулятивно-посередницького типу, організація і діяльність яких далека від принципів реформи, виробничої сфери, дієвого економічного регулювання, від реального впливу на подолання економічної кризи.

Відсутнє чітке розмежування прав і відповідальності, з одного боку, між федеральним центром і місцевими органами влади, 3 іншого - між апаратом президента, урядом і законодавчими органами. Це викликає дублювання, підміну ролей i функцій, неможливість ефективно використовувати владні повноваження [18].

За великим рахунком, криза сучасного державного управління $\epsilon$ наслідком зростання проблеми, з якою стикається та чи інша держава. Ця криза виражена у неспроможності державних органів впоратися з викликами інноваційного розвитку [19]. Врешті-решт, така криза зумовлена неможливістю або складністю впровадження гнучких інструментів управління. На думку автора, такі особливості $є$ найбільш характерним на адміністративному рівні (хоча $\mathrm{i}$ на інших рівнях, політичному та інформаційному, державі бракує кваліфікованої ідентифікації суті проблеми, виявлення завдань та обмеження їх рішень, формування та розповсюдженні інформації).

Так само як і визначень, у сучасному науковому дискурсі існує чимало класифікацій криз. Зобразимо схематично деякі з них.

Першою слід взяти до увагу класифікацію організаційних криз О.Лербінгера[16], щоскладаєтьсязвосьмитипівкриз.Авторвиокремлював природну катастрофу, технологічну кризу, кризу протистояння (конфронтаційна криза), кризу зловмисності, організаційні проступки (неналежне виконання службових обов' язків), насильство на робочому місці, чутки і терористичні атаки / техногенні катастрофи (Табл. 1). 
Табличя 1.

\section{Класифікація та характристика організаційних криз за О. Лербінгером}

\begin{tabular}{|c|c|c|c|}
\hline № & $\begin{array}{l}\text { Вид кризи за } \\
\text { Лербінгером }\end{array}$ & Характеристика кризи & Приклад \\
\hline 1 & $\begin{array}{c}\text { Природна } \\
\text { катастрофа }\end{array}$ & $\begin{array}{l}\text { Кризи, пов'язані зі стихійними } \\
\text { лихами - це такі явища } \\
\text { навколишнього середовища, як } \\
\text { землетруси, виверження вулканів, } \\
\text { торнадо та урагани, повені, зсуви, } \\
\text { цунамі, шторми та посуха, які } \\
\text { загрожують життю, майну та самому } \\
\text { навколишньому середовищу. }\end{array}$ & $\begin{array}{c}\text { землетрус в } \\
\text { Індійському } \\
\text { океані } 2004 \text { р. } \\
\text { (Цунамі). }\end{array}$ \\
\hline 2 & $\begin{array}{c}\text { Техноло- } \\
\text { гічна } \\
\text { криза }\end{array}$ & 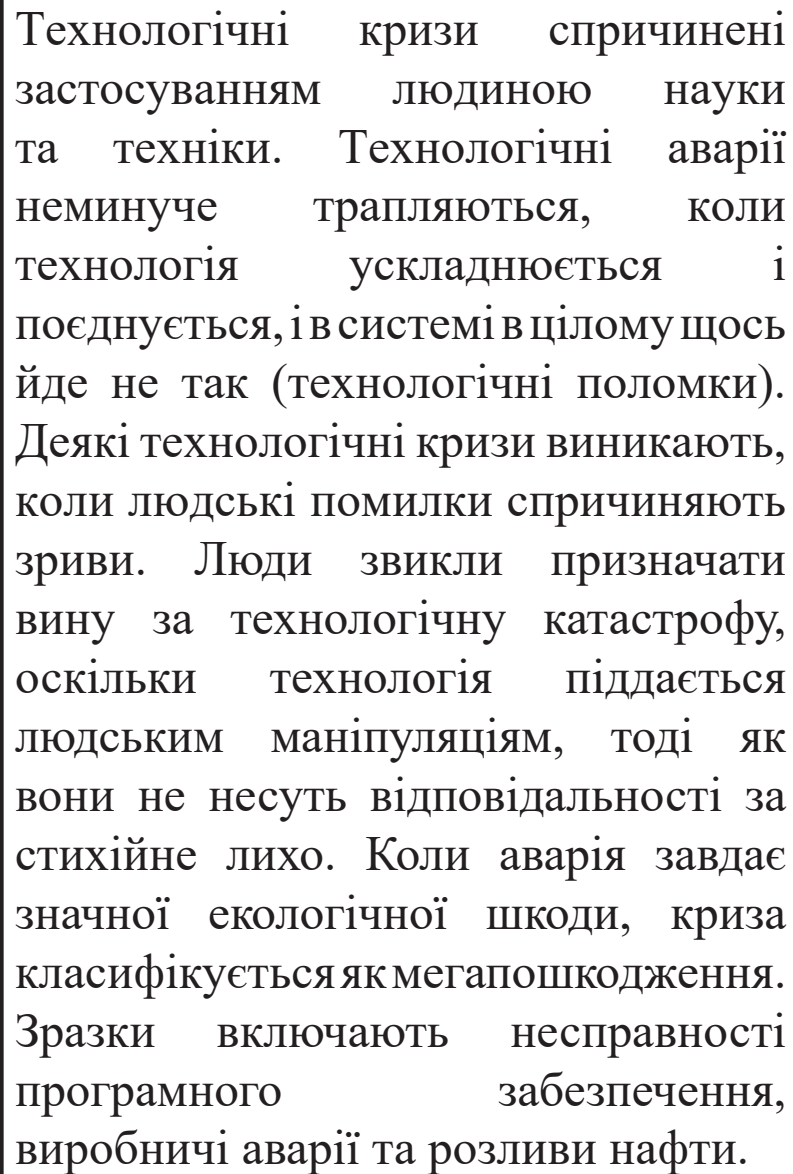 & $\begin{array}{c}\text { Чорнобильська } \\
\text { катастрофа, } \\
\text { розлив нафти } \\
\text { Exxon Valdez, } \\
\text { помилка } \\
\text { безпеки } \\
\text { Heartbleed. }\end{array}$ \\
\hline
\end{tabular}




\begin{tabular}{|c|c|c|c|}
\hline 3 & $\begin{array}{c}\text { Конфронта- } \\
\text { ційна } \\
\text { криза }\end{array}$ & $\begin{array}{l}\text { Криза конфронтації виникає, коли } \\
\text { невдоволені особи та / або групи } \\
\text { борються } 3 \text { бізнесом, урядом та } \\
\text { різними групами інтересів, щоб } \\
\text { отримати прийняття іхніх вимог } \\
\text { та очікувань. Поширеним типом } \\
\text { конфронтаційної кризи є бойкот, } \\
\text { а іншими видами є пікетування, } \\
\text { ультиматуми тим, хто має владу, } \\
\text { блокада чи окупація будівель, а } \\
\text { також опір чи непокора поліції. }\end{array}$ & $\begin{array}{c}\text { бойкот фірми } \\
\text { Nike збоку } \\
\text { Rainbow/ } \\
\text { PUSH's (People } \\
\text { United to Serve } \\
\text { Humanity) }\end{array}$ \\
\hline 4 & $\begin{array}{c}\text { Криза } \\
\text { зловмисності }\end{array}$ & 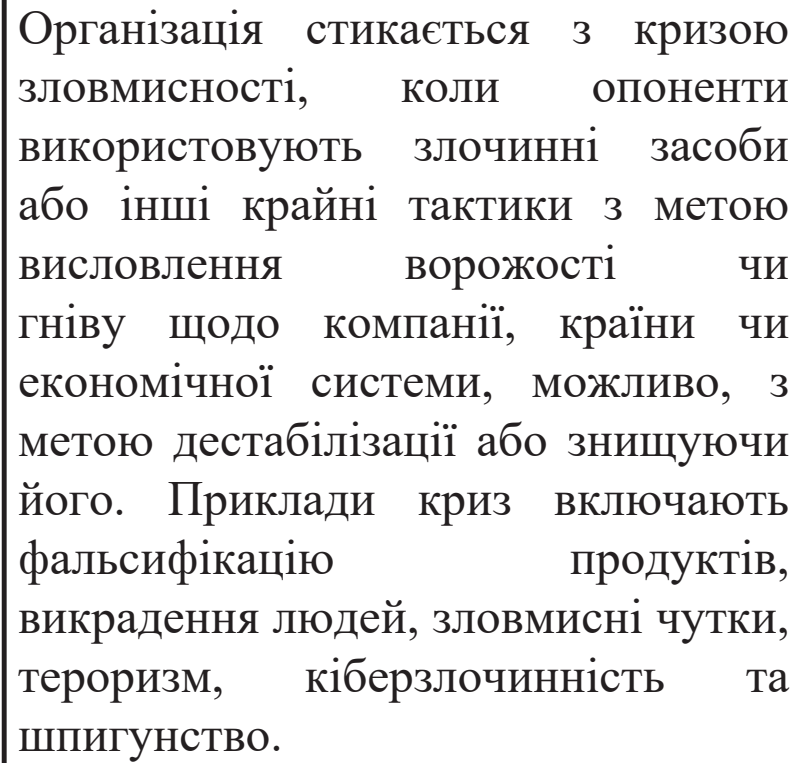 & $\begin{array}{c}\text { Чиказькі } \\
\text { вбивства } \\
\text { Тайленол }\end{array}$ \\
\hline 5 & $\begin{array}{c}\text { Організаційні } \\
\text { проступки }\end{array}$ & $\begin{array}{l}\text { Кризи виникають, коли керівництво } \\
\text { вживає дій, які, на його думку, } \\
\text { завдадуть шкоди або поставлять } \\
\text { зацікавлених осіб під загрозу } \\
\text { заподіяння шкоди без належних } \\
\text { запобіжних заходів. Лербінгер } \\
\text { вказав трирізнітипи криз, пов’язаних } \\
\text { із організаційними проступками: } \\
\text { кризи з перекосом управлінських } \\
\text { цінностей, кризи обману та } \\
\text { кризи, пов’ язані } 3 \text { неправомірною } \\
\text { поведінкою керівництва. }\end{array}$ & $\begin{array}{c}\text { Силікон- } \\
\text { гелевий } \\
\text { імплантант } \\
\text { Dow Corning }\end{array}$ \\
\hline
\end{tabular}




\begin{tabular}{|c|c|c|c|}
\hline 6 & $\begin{array}{c}\text { Насильство } \\
\text { на робочому } \\
\text { місці }\end{array}$ & $\begin{array}{l}\text { Кризи трапляються, коли працівник } \\
\text { чи колишній працівник здійснює } \\
\text { насильство щодо інших працівників } \\
\text { на організаційних підставах. }\end{array}$ & $\begin{array}{c}\text { Скандал, } \\
\text { пов’язаний } 3 \\
\text { Б. Клінтоном } \\
\text { та Монікою Л. }\end{array}$ \\
\hline 7 & Чутки & 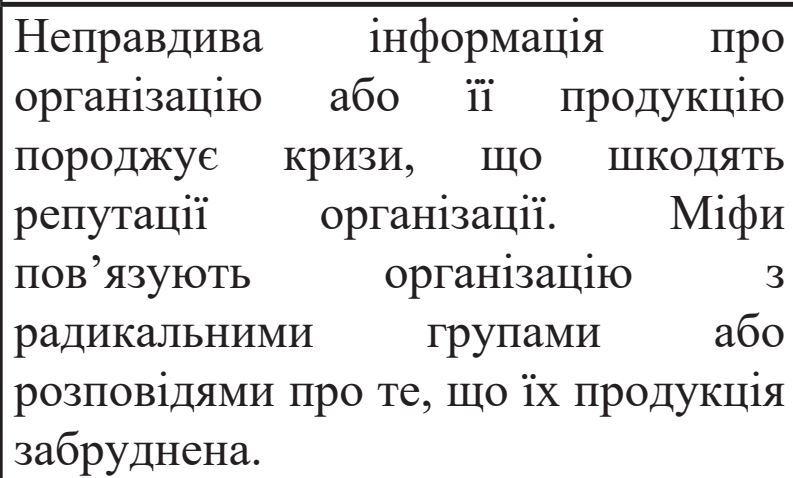 & $\begin{array}{l}\text { Мiф про } \\
\text { логотип } \\
\text { Procter \& } \\
\text { Gamble }\end{array}$ \\
\hline 8 & $\begin{array}{c}\text { Терористич- } \\
\text { ний акт }\end{array}$ & $\begin{array}{l}\text { Вони трапляються } \\
\text { коді, коли } \\
\text { нриз спричинили } \\
\text { налаштовані ладикально } \\
\text { Наприклад, внд, екстремісти. } \\
\text { мілітариських дій виникли глобальні } \\
\text { фінансові кризи, транспортні аварії, } \\
\text { масові руйнування. }\end{array}$ & $\begin{array}{c}\text { Терористич- } \\
\text { ний акт у } \\
\text { США, що } \\
\text { стався } 11 \\
\text { вересня } 2001 \\
\text { року }\end{array}$ \\
\hline
\end{tabular}

Дана класифікація є вкрай універсальною. Така типологія вдало інтегрується як у контекст антикризивого менеджменту комерційних організацій, так і у контекст державного управління, що за своєю природою, методами боротьби та причинами майже не відрізняється від приватного управління.

Слід зазначити, що на державному рівні діють практично ті ж самі принципи та механізми управління кризами, що й на корпоративному рівні.

Подібно до комерційних, державні організації під час кризових подій мають дотримуватися принципів оперативності, відкритості, чесності у поширенні інформації про кризу та іiї причини, виявляти співчуття i турботу постраждалим, постійно взаємодіяти із засобами масової інформації, вчасно повідомляти про вжиті заходи 3 врегулювання ситуації та щодо уникнення подібних ситуацій у майбутньому. 
За іншою класифікацією «криз» основним критерієм виступають «епіцентр кризи» та час ескалації. Такі кризи поділяються на:

- раптові кризи (висока швидкість прибуття, можливий будьякий епіцентр, наприклад: взяті заручники, теракти, відключення електроенергії);

- швидко спалюючи кризи (висока швидкість прибуття, низька стійкість після гострої стадії, будь-який епіцентр можливий, але, швидше за все, буде індивідуальним, політичним, інституційним, суспільним або промислово/технологічні, напр. спекотні хвилі, епізоди забруднення води);

- повзучі кризи - будь-який можливий епіцентр, особливий акцент на низькій швидкості ескалації, високій передбачуваності та низькому рівні готовності, наприклад: зміна клімату, ожиріння, старіння населення;

- кризи 3 довгою тінню (можливий будь-який епіцентр, але особливо ймовірно, що це буде на суспільному рівні; високий рівень стійкості після гострої стадії, наприклад: масові заворушення у великих містах, ядерні катастрофи);

- кризи, що визначають порядок денний (епіцентр, швидше за все, буде на індивідуальному, політичному, інституційному, суспільному, промисловому / технологічному рівнях, з високим рівнем політизації та високим рівнем наполегливості після гострої стадії, напр. масові розстріли, великі недоліки бюджету);

- неправильно керовані кризи (епіцентр, швидше за все, індивідуальний, політичний та інституційний, 3 акцентом на низький рівень підготовленості та високий рівень несприятливої політизації, наприклад будь -яка криза, що викликає істотну критику за неефективне управління кризою);

- виробничі кризи (наголос на високому рівні наміру викликати кризу. Епіцентр швидше за все, буде політичним чи інституційним, наприклад будь -яка криза, коли є звинувачення створення та/або роздування загрози до одного з критичних розмірів;

- політичні фіаско/катастрофи (епіцентр, ймовірно, буде політичним (а іноді і індивідуальним) та інституційний) з акцентом на високий рівень передбачуваності та високий ступінь політизації, 
наприклад: будь -яка істотна політика, де наслідки очевидні суттєве невиконання цілей політики викликає високий рівень негативної політизації для політиків та звинувачення в тому, що «вони мали бачити, що це буде», і близьким неминучість невдачі;

- технологічні кризи (епіцентр є технологічним, хоча він може поширитися і на політичний, інституційний, суспільний і навіть міжсоціальний рівні. Часто буде робитися акцент на високих рівнях складності, напр. збій у критичній IT -інфраструктурі);

- транскордонні кризи (епіцентр є міжсуспільним, хоча він охоплює також інші епіцентри, зокрема політичні, інституційні, суспільні, технологічні та геофізичні. Акцент також на високому рівні складності, наприклад: пандемії, економічні зриви);

- мегакризи (можливі всі епіцентри, але, ймовірно, акцент буде зроблений на суспільстві, міжсуспільний, технологічний та геофізичний. Також, ймовірно, буде наголос про високий рівень складності та високий рівень політизації, наприклад: глобальний провал Росії Інтернет);

- природні катастрофи (епіцентр є геофізичним, хоча може поширитися на всіх інші епіцентри). Великий акцент робиться на природних причинах, але немає навмисного заподіяти шкоду. Дебати також будуть обертатися навколо швидкості прибуття, ступеня передбачуваність та рівень підготовленості, наприклад: цунамі, лісові пожежі, землетруси, селі;

- аварії (епіцентри мають тенденцію включати аспекти технології, хоча вони також можуть бути суспільним. Акцент робиться на мало або зовсім немає навмисності викликати невдачі, наприклад: майор хімічні витоки, «дружній вогонь» під час війни);

- надзвичайні ситуації (акцент на індивідуальних та інституційних епіцентрах з високою швидкістю прибуття, високий ступінь передбачуваності та високий рівень підготовленості, наприклад: пожежі, ДТП).

Однак, слід звернути увагу і на іншу класифікацію, що чіпляє проблеми виключно державного управління. Так, Г. Купряшин виокремлював три види адміністративно-політичних криз, а саме кризу легітимності, кризу координації та кризу підзвітності [13]. 
Криза легітимності - це криза ціннісних засад органів державного управління, коли певні культурні коди стають перешкодою на шляху інституційної трансформації. Якщо зазвичай результати політики оцінюються в рамках категорій «ефективність», «економічність» та «результативність» та узгоджується з певними формально вираженими цілями (місіями, завданнями), то синдром модернізації змінює ставлення до цілей. На перший план виходять культурні очікування та норми. Звідси виникає значимість етичної оцінки підсумків управлінської діяльності.

Криза координації - це вади політичної координації діяльності органів державного управління. У результаті, така координація стає неузгодженою з існуючим адміністративним потенціалом, що призводить до постійних протиріч між політичними завданнями та адміністративними можливостями системи державного управління.

Криза підзвітності - це різке падіння дієвості стандартів, санкцій і каналів комунікації між акторами державних регуляторних рішень. У звичайній ситуації актори підзвітності зобов'язані діяти відповідно до існуючих норм, в іншому разі до них будуть застосовуватися передбачені санкції (покарання) за нездатність виконати доручене. У свою чергу, норми (стандарти) і санкції зв>язані за допомогою відповідних каналів комунікації, через які регулярно поставляється необхідна інформація: в одну сторону (підлеглим, тобто агентам) про зміст норм, в іншу (що володіє владними повноваженнями, тобто принципалам) - про міру відповідності (розбіжності) між нормою і реальними діями.

На думку автора, дисфункція державного управління - це наслідок зазначених вище криз, що проявляється в нездатності держави вирішити три фундаментальні завдання. По-перше, держава має сприяти формуванню інституційної бази розвитку. По-друге, держава покликана бути організатором координації взаємодій громадських i, перш за все, економічних агентів. Потретє, держава має залучити до публічних справ тих агентів, які за своєю природою орієнтовані на приватні інтереси.

За іншою класифікацією, пердставленою Фаразмандом, існує багато типів кризових ситуацій. Однак, ми можемо розмежувати 
усі типи на дві групи: раптові кризи (наприклад, цунамі, теракт чи вибух ядерного реактора) та повзучі кризи (наприклад, поширення вірусу або глобальне потепління) [20].

Очевидно, що найскладніше впоратися з кризою, що швидко розвивається, оскільки ступінь готовності уряду до невідкладних дій дуже низький. 3 іншого боку, в умовах повільно розростаючих криз, таких як повзучі кризи, і у випадку низького рівня обізнаності уряду про них, кризові події можуть завдати довгостроковий вплив і незворотні збитки.

Відповідно до класифікації криз С. Катліпа, А. Сентера та Г. Брума, де критерієм виступає тривалість розвитку, кризи поділяються на неочікувані, назріваючі та безперервні [10].

Перші відбуваються раптово, не лишаючи часу для підготовки та планування (авіакатастрофи, псування продуктів, смерть керівника, землетрус тощо). Такі кризи потребують своєчасного узгодження плану дій, який дозволив би уникнути непорозумінь, суперечок та неоперативного реагування.

Другі, а саме «назріваючі кризи», дають більше часу для вивчення і планування, але можуть раптово виникнути після тривалого визрівання. До цієї категорії відносяться незадоволеність працівників та негативний моральний клімат в колективі або суспільстві. У такому випадку керівництву необхідно вжити відповідних заходів ще до того моменту, коли криза виникне i досягне руйнівної фази.

Стосовно третього типу, а саме «безперервних криз», слід зазначити, що вони можуть тривати впродовж місяців або років, абсолютно ігноруючи будь-які зусилля наїх подолання. Здебільшого, непідконтрольними організації можуть стати чутки, плітки або спекуляції, що їх передають засоби масової інформації. Всі спроби спростувати викривлену інформацію не дають результатів, оскільки журналісти використовують попередні публікації і знову відтворюють дезінформацію.

Цікавою у даному контексті є класифікація Сема Блека, що запропонував поділити кризи за рівнем негараздів, які вони здатні заподіяти організації [14]. Авторський підхід характеризувався 
спробою переходу від загальної типологізації криз за родовою ознакою до класифікації, що безпосередньо наближується до змісту і сфери діяльності організації.

Відповідно до авторської класифікації, кризи поділяються на «відомо невідомі» та «невідомі невідомі». Наприклад, у першому випадку відомо, що аварія в принципі можлива, але чи вона станеться і якщо так, то коли - невідомо. У другому мова йде про катастрофи, що неможливо попередити. Як приклад можна взяти порушення технології, що може призвести до отруєння продуктів, або терористичну атаку.

Кризи за тривалістю та серйозністю наслідків, класифікуються на гострі, хронічні та спустошливі [5]. До перших відносяться аварії та непередбачувані події, тобто випадки, що спричиняють тимчасове порушення нормальної соціальної діяльності, значні економічні збитки та людські жертви у суспільстві. До другої можна віднести лиха різного типу, тобто події, що призводять до довгострокового або значного розриву в соціальних комунікаціях та соціальних структурах. Такі події можуть стати причиною загибелі людей та/або значного погіршення здоров'я та / або забруднення навколишнього середовища, а також завдати значних матеріальних збитків, які певним чином можна компенсувати, але за великий проміжок часу. Треті, або спустошливі кризи - це катастрофи $\mathrm{i}$ катастрофічні лиха, події, що спричиняють порушення соціальної комунікації та роботи суспільних структур й супроводжуються численними жертвами, масовою шкодою здоров'ю людей та забрудненням навколишнього середовища, високим рівнем стресу постраждалих, дуже великими і практично незворотними соціальними, екологічними та матеріальними збитками, які можна відновити лише в далекому майбутньому.

Варто зазначити, що бізнес як невід'ємна частина сучасного суспільства має свою класифікацію криз. За великим рахунком, у даній сфері усі кризи поділяються на фінансові, що характеризуються нестачею коштів в короткотерміновому аспекті та банкрутством - у довготерміновому; на кризи зв'язків із громадськістю (комунікаційні кризи) що відображаються у негативних публікаціях у ЗМI, що 
у свою чергу можуть нашкодити як репутації компанії, так і іiі діяльності зокрема; а також на стратегічні кризи, що відзначаються зміною у навколишньому середовищі, у суспільстві. Такі кризи ставлять під питання саме існування компанії. Як приклад: масове використання комп’ютерної продукції спричинило стратегічну кризу для виробників друкарських машинок.

Спробуємо екстраполювати дану класифікацію на рівень публічного управління. Так, фінансова криза стає результатом неможливості держави виконання своїх боргових зобов'язань (так званий дефолт). Криза зв'язків із громадськістю тоді буде представлена у якості появи критичних публікацій про діяльність урядових структур, що у свою чергу є частиною цілеспрямованої інформаційної кампанії проти уряду або реакцією на непопулярні урядові дії. Врешті-решт, стратегічна криза може виникнути внаслідок як внутрішніх змін (наприклад, незаконне захоплення влади в країні та як наслідок - зміна напряму розвитку або навіть зміна устрою), так і зовнішніх (воєнні конфлікти в сусідніх державах).

Кризи створюють нові складні та неоднозначні ситуації, тим самим впливаючи на процес прийняття управлінських рішень. У даному контексті дослідник Г. Сімон характеризує такі рішення як непрограмовані, маючи на увазі рішення щодо нестандартних проблем, які ухвалюються під впливом зовнішніх факторів. На думку автора, складність таких рішень полягає у тому, що вони непідвладні звичайному аналізу та процедурам. Крім того, вони характеризуються високим ступенем невизначеності та мають бути ухвалені якомога раніше [3].

Особи, які ухвалюють рішення, у кризових умовах зазвичай дають найпростіші відповіді, що вже довели свою ефективність у минулому, та зосереджують увагу на одномоментних рішеннях, які уможливлять швидке врегулювання ситуації, що склалася.

Бувають ситуації, коли під час вироблення управлінської лінії поведінки обирається один напрям дій і він сприймається як неминучість, при тому, що відповідальна особа (посадова особа) усвідомлює обмеженість вибору і значні втрати. 
Як правило, така розбіжність між діями особи та реальним усвідомленням нею наслідків пом'якшується двома способами: або шляхом звільнення посадової особи від відповідальності за рішення, тобто визнання за офіційною особою права зробити неправильний вибір за умови, що реально неможливо зробити правильний вибір; або шляхом перекладення відповідальності за відвернення кризи на опонента.

Під час кризи обсяг інформації може зростати, що знижує якість обробки даних, і особа, яка приймає рішення, суб'єктивно виокремлює те, що їй здається важливим. Це може знизити ймовірність прийняття стратегічно правильного рішення.

Слід також зазначити, що кризи у державному управлінні розвиваються поетапно. У своїй праці В. Герасенко стверджував, що розвиток кожної кризи супроводжується трьома етапами [7].

1) Поява значної кількості конфліктних центрів у різних сферах суспільного життя.

2) Конфлікт, що розвинувся у соціальній площині, ескалується до такого ступеня, що знаходження компромісного рішення стає неможливим.

3) Криза розвивається та загострюється до максимальних масштабів, зумовлюючи розпад наявних політичних структур. Третій етап ілюструє найбільш масштабну, загальносистемну кризу [7].

Також автор зазначав, що загальносистемна криза характеризується певною несумісністю магістральних складових (компонентів) суспільства (політика, економіка, соціальна сфера тощо). У випадку такої кризи, віднайти гармонію, рівновагу у системі стає неможливим завданням у межах наявного політичного i соціально-економічного устрою.

Врешті-решт, у даному контексті необхідно сказати кілька слів про методи, завдяки яким слід вивчати кризи у публічному управлінні. Звичайно, їх чимало. Це і теоретичні (аналіз, синтез, класифікація, індукція, дедукція тощо), і емпітричні методи (спостереження, експеримент, інтерв'ю), а також як «кількісні», так i «якісні» дослідження. Однак, варто виокремити один метод, що має певну перевагу над всіма іншими. 
Одним із інструментів, який став важливим методом вивчення та управління кризою, $є$ сценарії, які використовуються для прогнозування причин, наслідків та вартості ряду можливих кризових подій та їх подальшої еволюції. Мова йде про метод побудови сценаріїв, який використовуються здебільшого для прогнозування причин, наслідків та вартості ряду можливих кризових подій та їх подальшої еволюції. У багатьох галузях дослідження використання сценаріїв як основи для прогнозування ризиків є загальновизнаним методом планування криз, включаючи екологічні, економічні, природні та навіть численні події [15].

Невід'ємним аспектом дослідження криз є динаміка їх розвитку.

У даному контексті слід розглянути модель, запропоновану С. Фінком. За цією моделлю, будь-яка організаційна криза проходить чотири фази [6].

1. «Продромальна» фаза (з грецької «така, що посилає попереджуючі сигнали»). На даній стадії з'являються перші ознаки кризи.

2. Фаза «загострення», що характеризується швидким та інтенсивним розвитком подій. На цьому етапі проблема стає об'єктом пильної уваги громадськості та засобів масової інформації. Також цей етап характеризується порушенням нормальної діяльності органів публічного управління та появою загрози позитивному іміджу органів влади / держави та репутації керівників тощо.

3. «Хронічна фаза», для якої характерним є здійснення заходів щодо подолання причин кризи, які виникли на попередній стадії. Також для даної фази характерним $є$ відновлення нормальної роботи, а також процес «самоаналізу» серед керівництва. Слід також додати, що у цей період здійснюються спроби пояснити дві речі: по-перше, як управлінські структури функціонують, і по-друге, які елементи організаційної культури є дисфункціональними чи становлять перешкоду для підвищення прибутковості та рівня довіри громадськості. Хронічна фаза найдовша з усіх. Для того, щоб скоротити iіi, органи влади мають розробити плани кризового управління. За твердженням С. Фінка, структури, які не мають таких планів, потерпають від затяжного впливу кризи у два 
3 половиною рази довше, ніж структури, які розробили плани управління кризами [6].

4. Остання, четверта фаза, що описується автором як «стадія вирішення кризи». Це період повного «одужання» інституції від кризи. Однак, автор наголошує, що ця фаза потребує від керівництва організації пильності й готовності до появи ознак нових проблем.

Однак, кризи створюють не тільки загрози, а й певні можливості, серед яких слід виокремити:

- можливість переведення серйозних суспільних питань у дискусійну площину;

- можливість здійснення організаційних змін та навчання для забезпечення кращої профілактики та готовності до майбутніх загроз;

- можливість посилення статків ефективних лідерів.

Також слід зазначити, що будь-яка «криза»є каталізатором покарання слабких та/або неефективних лідерів; та надання можливості деяким організаціям «проявити» себе та лобіювати для довгострокового збільшення фінансування.

Висновки. Криза у загальному розумінні - це нестабільний або вирішальний час чи стан справ, у яких насувається рішуча зміна, або ситуація, яка досягла критичної фази. Кризові ситуації малоймовірні події, які загрожують цілісності та існуванню організації. Ми визначаємо кризу публічного управління як момент загострення (політичних, економічних, соціальних) протиріч, що призводить до певних змін у системі (організації, державі, тощо).

Кризи - це складний феномен, який впливає на широкий спектр подій. Кризи різняться за багатьма ознаками. Критерієм відмінності виступають: масштаб, причини, тривалість, серйозність наслідків тощо. У свою чергу, вони є подібними одна до одної у тому сенсі, що здатні створювати загрозу інтересам організації, уряду чи державі, впливати на їх репутацію. Кризи потребують негайного реагування. Для подолання криз вкрай необхідним $є$ застосування нетрадиційних засобів врегулювання, що здатні суттєво змінити ситуацію, відновити оптимальний хід життя суспільства й налагодити відносини між усіма сторонами, що причетні до конфлікту. Несвоєчасне реагу- 
вання на кризи здатне не лише завдати матеріальних збитків, але й вплинути на цілі організації та держави, спричинивши невідворотні втрати.

Не підлягає сумнівам, що криза є негативним явищем. Однак, криза може призвести не лише до негативних, а i до деяких позитивних наслідків. Так, криза може стати стимулом для вдосконалення системи. Посткризовий процес відбудови міг би дати результати, кращі за докризову ситуацію. Окрім того, уряду також надається можливість дізнатись про власні слабкі сторони i, як результат, покращити здатність реагувати на майбутні кризові події.

Та все ж таки, кризи залишаються вкрай загрозливим явищем. Як свідчить практика, ймовірність помилок і прорахунків у виборі контрпродуктивних стратегій реагування на надзвичайну подію $\epsilon$ дуже високою. Особливо помилки з'являються в умовах обмеженого часу для ухвалення рішень. Саме тому подальші дослідження криз вбачаються вкрай актуальними і перспективними.

\section{Стаття надійшла до редакції:15.06.21}

\section{THEORETICAL AND METHODOLOGICAL FOUNDATIONS OF RESEARCHING CRISES IN PUBLIC ADMINISTRATION}

Oleksandr Sokolov, National University of Life and Environmental Sciences of Ukraine, Kyiv, Ukraine postgraduate student of the Department of International Relations and Social Sciences, Kyiv, Ukraine.

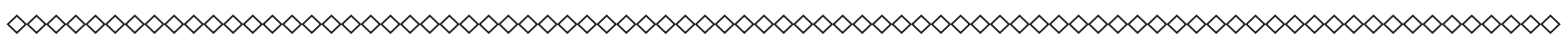

The purpose of the article is to determine the theoretical and methodological foundations of the study of crises in public administration. The methodological basis of the study are general theoretical methods (analysis and synthesis), as well as the principles of historicism, objectivity and science. The scientific novelty lies in the unique author's 
definition and analysis of crises in public administration. Conclusions. It has been studied that a crisis in the general sense is an unstable or critical period that inevitably leads to change and contains a high probability of extremely undesirable consequences. In turn, the "crisis of public administration" is a special form of system of public authorities and civil society, accompanied by instability, reduced control over socioeconomic processes, imbalance of political institutions, exacerbation of social conflicts, growing contradictions in society and more. Such a crisis leads to a decrease in the effectiveness and efficiency of managerial influence on socio-economic processes.

The crisis is considered as a complex phenomenon covering a wide range of events. These events may differ in scale, causes, duration, severity, etc., but they are united by the fact that they threaten the main interests and reputation of the organization, government or state, require immediate response and the use of non-traditional means of settlement, significantly change the situation, normal course. society and relations between the parties to the conflict. It is analyzed that public administration crises can be both mild and deep, both short-term and prolonged, both local and continuous, both hidden and overt, both acute and chronic. It was found that in case of ignoring or untimely response to crises, they can not only cause material damage, but also negatively affect the goals of the organization and the state.

Key words: state power, crisis, methodology, public administration, theory.

\section{Received: 15.06.21}

\section{References}

1. Bielai, S., Korniienko, D., \& Kotukha, O. (2018). Research the crisis indicators impact of the socio-economic character on the ensuring of the state security. Baltic Journal of Economic Studies, 4(4), (pp. 33-38). https://doi. org/10.30525/2256-0742/2018-4-4-33-38 [in English].

2. Building the Future (2017): The EU's Contributions to Global Governance. Challiot Paper, 100. (pp. 67-72) [in Engish]. 
3. Crump J. (2019). Cyber Crisis Management Planning: How to reduce cyber risk and increase organizational resilience [in English].

4. Do, B.N., Nham, T.P., \& Nguyen, T.M. (2019). An investigation the main internal brand crisis antecedents. Business: Theory and Practice, 20, (pp. 234-247). https://doi.org/10.3846/btp.2019.23 [in Engish].

5. Drennan, L.T., McConnell, A., \& Stark, A. (2014). Risk and crisis management in the public sector. Routledge [in English].

6. Fink S. (1986). Crisis Management: Planning for the Inevitable. New York, NY: American Management Association [in English].

7. Gerasenko, V. (2000). Antikrizisnoe upravlenie - osnova stabilizatsii ekonomiki (metodologicheskie aspekty) [Anti-crisis management - the basis for stabilizing the economy (methodological aspects)]. Visn. tekhnol. untu Podillya. Ser.: ekon. Nauki - Bulletin of the Technological University of Podillya. Series: Economic Sciences, 4 (3), (pp. 30-35) [in Russian].

8. Haine J.Y. (2004) ESDP: An Overview. ESDP: The First Five Years (1999-2004). Challiot Papers, (pp. 131-142) [in English].

9. Ilchuk, P., Viblyi, P., \& Lashchyk, I. (2018). Theoretical and methodological aspects of the anti-crisis capacity of enterprises. Baltic journal of economic studies, 4(3), (pp. 88-93). https://doi.org/10.30525/22560742/2018-4-3-88-93 [in English].

10. Katlip, S.M., Tsenter, A.Kh., \& Brum, G.M. (2003). Pablik rileyshnz. Teoriya i praktika. [Public relations. Theory and practice]. (8nd ed.). Moskva: Izdatelskiy dom «Vilyams» [in Russian].

11. Korotkov, E. (2011). Antikrizisnoe upravlenie predpriyatiyami [Anticrisis management of enterprises]. Moskva: INFRA [in Russian].

12. Kostecjka, L. (2016). Antykryzovyj menedzhment u derzhavnomu upravlinni [Anti-crisis management in public administration]. Visnyk Nacionaljnoji akademiji derzhavnogho upravlinnja pry Prezydentovi Ukrajiny. Serija: Derzhavne upravlinnja - Bulletin of the National Academy of Public Administration under the President of Ukraine. Series: Public Administration, 4, (pp. 87-92) [in Ukrainian].

13. Kupryashin, G. (2015). Krizisy gosudarstvennogo upravleniya: neoinstitutsionalnyy podkhod [Public administration crises: a neo-institutional approach.]. Gosudarstvennoe upravlenie - Public administration, 51. Retrieved from https://cyberleninka.ru/article/n/krizisy-gosudarstvennogo-upravleniyaneoinstitutsionalnyy-podhod. [in Russian]. 
14. Kvyat, A.G. (2012). Sem Blek 2.0. svyazi s obshchestvennostyu v epokhu «Globalnoy derevni». [2.0. public relations in the era of the «Global Village»]. Vestnik sotsialno-gumanitarnogo obrazovaniya i nauki-Bulletin of social and humanitarian education and science, 1, (pp. 38-41) [in Russian].

15. Laws, E., \& Prideaux, B. (2006). Crisis management: A suggested typology. Journal of Travel \& Tourism Marketing, 19(2-3), (pp. 1-8) [in English].

16. Lerbinger, O. (1997). The crisis manager: Facing risk and responsibility. Mahwah, NJ: Erlbaum, (pp. 117-120) [in English].

17. Merriam Websster (1828). (n.d.). www.merriamwebster.com. Retrieved from https://www.merriamwebster.com/dictionary/crisis [in English].

18. Milner, B (1993). Krizis upravleniya [Management crisis]. Zhurnal «Voprosy ekonomiki» - Journal «Questions of Economics», 1, (pp. 79-91) [in Russian].

19. Obolonskiy, A. (2014). Krizis effektivnosti administrativno-byurokraticheskogo gosudarstva i poiski vykhoda: opyt SShA (evolyutsiya teorii i praktiki gosudarstvennogo upravleniya $\mathrm{v}$ poslednie desyatiletiya) [The crisis of the effectiveness of the administrative-bureaucratic state and the search for a way out: the experience of the United States (evolution of the theory and practice of public administration in recent decades)]. Voprosy gosudarstvennogo i munitsipalnogo upravleniya - Issues of state and municipal administration, 2, (pp. 145-170) [in Russian].

20. Putra, F. (2009). Crisis management in public administration [in English].

21. Yegorov, A. (2013). Krizisy v istorii Rima (sobytiya i problemy) [Crises in the history of Rome (events and problems)]. Mnemon. Issledovaniya $i$ publikatsii po istorii antichnogo mira. Sbornik statey $k$ 80-letiyu so dnya rozhdeniya prof. E. D. Frolova-Mnemon. Research and publications on the history of the ancient world. Collection of articles dedicated to the 80th anniversary of the birth of Professor E.D. Frolova, 12, (pp. 346-365) [in Russian].

22. Zub, A. (2005). Antikrizisnoe upravlenie [Crisis management]. Moskva: Aspekt press [in Russian]. 
Відомості про автора / Information about the Author

Соколов Олександр Єгорович: Національний університет біоресурсів і природокористування України: вул. Героїв Оборони, 15, Київ, 03041, Україна.

Alexander Sokolov: National University of Life and Environmental Sciences of Ukraine, str., Heroiv Oboroni, 15, Kiev, 03041 Ukraine.

ORCID. ORG./ 0000-0002-7185-296X

E-mail: mr.sokolov.alexandr@gmail.com 